\title{
HUBUNGAN ANTARA KEBISINGAN DAN FUNGSI PENDENGARAN PADA PETUGAS PT. GAPURA ANGKASA DI BANDAR UDARA SAM RATULANGI MANADO
}

\author{
${ }^{1}$ Fauziah N Manoppo \\ ${ }^{2}$ Wenny Supit \\ ${ }^{2}$ Vennetia R Danes \\ ${ }^{1}$ Kandidat Skripsi Fakultas Kedokteran Universitas Sam Ratulangi Manado \\ ${ }^{2}$ Bagian Fisika Fakultas Kedokteran Universitas Sam Ratulangi Manado \\ Email: fauziah_manoppo@yahoo.com
}

\begin{abstract}
The noise resulted from the advancement of transportation is an issue that cannot be avoided. The Noise Induced Hearing Loss is a decreases of auditory type sensorineural, which is initially not be aware, because there has not disturbed of daily conversation yet. Risk factors that affect the degree of severity of deafness are the intensity of the noise, frequency, long exposure per day, long working period, individual sensitivity, age and other factors that could influence. The aim of this research is to find out whether there is a relationship between noises by function of hearing at the officers of PT. Gapura Angkasa at Sam Ratulangi Airport, Manado. The Method of this research namely the analytic method is a design cross sectional study, and the samples were 20. The Measurement of noise levels is based on a unit of work the Operation which was obtained at the level of $75 \mathrm{~dB}$ and $85 \mathrm{~dB}$ Loading. From the results obtained from 20 staffs there are only 8 people who work exceed the Threshold Value (NAB) of noise which has been set. Conclusion: The result showed that there is hearing loss about $20 \%$ in all the officers. The result Analysis Bivariat indicates that there is the absence of meaningful relations between noise-induced hearing disorder with the level of intensity noisy $(p=0.591)$. From the results of this research it can be concluded that the officers who work in on high intensity noise are more at risk of experiencing hearing loss compared to the officers who work on a low intensity noise level. In addition, the factors such as long hours of work, long exposure noise, the use of Ear Protectors Tools (EPT) was also very influential of the onset hearing loss in workers.
\end{abstract}

Keywords: Noise Induced Hearing Loss, Sam Ratulangi Airport, The Officers of PT. Gapura Angkasa.

Abstrak: Kebisingan merupakan suatu masalah yang tidak dapat dihindari akibat kemajuan sarana transportasi. Gangguan pendengaran akibat bising adalah penurunan pendengaran tipe sensorineural, yang pada awalnya tidak disadari, karena belum mengganggu percakapan seharihari. Faktor risiko yang berpengaruh pada derajat parahnya ketulian ialah intensitas bising, frekwensi, lama pajanan perhari, lama masa kerja, kepekaan individu, umur dan faktor lain yang dapat berpengaruh. Tujuan penelitian ini untuk mengetahui apakah terdapat hubungan antara kebisingan dengan fungsi pendengaran pada petugas PT.Gapura Angkasa di Bandara Sam Ratulangi. Metode penelitian yang digunakan yaitu metode analitik dengan menggunakan rancangan studi cross sectional. Sampel berjumlah 20 orang. Pengukuran tingkat bising di lakukan berdasarkan unit kerja yaitu pada bagian Operation didapatkan $75 \mathrm{~dB}$ dan bagian 
Loading 85 dB. Dari hasil yang didapatkan dari 20 orang petugas hanya 8 orang saja yang bekerja melebihi NAB kebisingan yang telah ditetapkan. Simpulan : Hasil penelitian menunjukkan bahwa terdapat gangguan pendengaran sebesar 20\% pada seluruh petugas. Hasil analisis bivariat menunjukkan tidak adanya hubungan yang bermakna antara gangguan pendengaran dengan tingkat intesitas bising $(\mathrm{p}=0.591)$. Dari hasil penelitian ini dapat disimpulkan bahwa petugas yang bekerja pada intensitas bising yang tinggi lebih beresiko mengalami gangguan pendengaran dibandingkan dengan petugas yang bekerja pada tingkat intesitas bising yang rendah. Selain itu faktor-faktor seperti lama bekerja, lama pemaparan bising, penggunaan Alat Pelindung Telinga (APT) juga sangat berpengaruh terhadap terjadinya gangguan pendengaran pada petugas.

Keywords: Gangguan pendengaran akibat bising, Bandara Sam Ratulangi, Petugas PT. Gapura Angkasa.

Seiring dengan semakin meningkatnya pembangunan dalam segala bidang termasuk kemajuan teknologi membawa pengaruh negatif lainnya bagi kehidupan manusia. Salah satu sektor kemajuan yang sangat pesat adalah sarana transportasi yang dapat mempermudah dan juga mempercepat manusia dalam menjalankan suatu kegiatan. Kebisingan merupakan suatu masalah yang tidak dapat dihindari akibat kemajuan sarana transportasi tersebut. ${ }^{1}$

Gangguan pendengaran akibat bising adalah Penurunan pendengaran tipe sensorineural, yang pada awalnya tidak disadari, karena belum mengganggu percakapan sehari-hari. Sifat gangguannya adalah tuli sensorineural tipe koklea dan umumnya terjadi pada ke dua telinga. Faktor risiko yang berpengaruh pada derajat parahnya ketulian ialah intensitas bising, frekwensi, lama pajanan perhari, lama masa kerja, kepekaan individu, umur dan faktor lain yang dapat berpengaruh. Berdasarkan hal tersebut dapat dimengerti bahwa jumlah pajanan energi bising yang diterima akan sebanding dengan kerusakan yang didapat. ${ }^{2}$

Data survei Multi Center Study di Asia Tenggara, Indonesia termasuk 4 negara dengan prevalensi ketulian yang cukup tinggi yaitu 4,6\%, sedangkan 3 negara lainnya yakni Sri Lanka (8,8\%), Myanmar (8,4\%) dan India 6,3\%). Walaupun bukan yang tertinggi tetapi prevalensi $4,6 \%$ tergolong cukup tinggi, sehingga dapat menimbulkan masalah sosial di tengah masyarakat. $^{3}$

Taraf kebisingan telah diatur berdasarkan keputusan menteri tenaga kerja no.51/MEN/1999. Nilai ambang batas kebisingan yang diperkenankan menurut keputusan menteri tenaga kerja : 51/menaker/1999 adalah 85 dBA untuk lama pemaparan selama 8 jam sehari atau 40 jam dalam seminggu. ${ }^{4}$

Telinga dibagi dalam 3 bagian yaitu telinga luar, telinga tengah dan telinga dalam. ${ }^{5}$ Terdapat 2 jenis kelainan yang berhubungan dengan pemaparan bising yaitu trauma akustik dan gangguan pendengaran akibat bising (noise induced hearing loss/NIHL). Keduanya mengakibatkan kerusakan pendengaran dengan menyebabkan beberapa kerusakan pada telinga, terutama telinga dalam. Kerusakan telinga dalam sangat bervariasi dari kerusakan ringan pada sel rambut sampai kerusakan total organ korti. Segera setelah terjadi pemaparan bising yang mendadak dan merusak, sel-sel jaringan telinga dalam mengalami trauma, degenerasi atau perbaikan. Paparan bising pada fase akut dengan intensitas paparan $140 \mathrm{~dB}$ atau lebih, menyebabkan trauma akustik segera dan seketika terjadi kurang pendengaran. ${ }^{6}$ 


\section{METODE PENELITIAN}

Jenis penelitian yang digunakan adalah analitik dengan rancangan studi cross sectional. Waktu penelitian dilakukan pada bulan November 2013. Tempat penelitian dilakukan di Bandara Sam Ratulangi Manado, Sulawesi Utara. Populasi adalah semua petugas PT. Gapura Angkasa di Bandara Sam Ratulangi Manado. Sampel penelitian diambil berdasarkan kriteria inklusi yaitu : Terdaftar sebagai petugas lapangan PT. Gapura Angkasa di Bandara Sam Ratulangi, Tidak ada infeksi telinga, Usia 18-50 tahun, telah bekerja minimal satu tahun, bersedia sebagai subjek penelitian dengan mengisi lembar kuesioner, melakukan pemeriksaan fisik telinga dan audiometri serta bersedia menandatangani informed consent. Variabel penelitian terdiri dari dua variabel diantaranya variabel bebas yaitu Kebisingan dan variabel terikat yaitu Fungsi Pendengaran.

Pengambilan data diperoleh dari kuesioner. Sedangkan pengukuran tingkat kebisingan diperoleh dengan menggunakan alat sound level meter. Selanjutnya data diperoleh melalui pemeriksaan fungsi pendengaran dengan menggunakan alat audiometri. Analisis data dilakukan dengan uji fisher exact dengan menggunakan program SPSS.

\section{HASIL}

Tempat penelitian dilakukan di Bandara Sam Ratulangi yang berada di kecamatan Mapanget kota Manado, Sulawesi Utara. Pengukuran kebisingan diukur sesuai bagian kerja yaitu pada bagian Operation yang berjumlah 9 orang dengan tingkat kebisingan $\pm 75 \mathrm{~dB}$ dan bagian Loading yang berjumlah 11 orang dengan tingkat kebisingan $\pm 85 \mathrm{~dB}$.
Berdasarkan analisis univariat karakteristik responden dalam penelitian ini meliputi umur, lama menjadi petugas, durasi kerja, tingkat kebisingan, ketaatan pemakaian Alat Pelindung Telinga (APT), jenis APT, gangguan pendengaran telinga kanan, gangguan pendengaran telinga kiri. Untuk memperoleh gambaran distribusi menurut karakteristik responden dapat dilihat pada tabel berikut :

Tabel 1. Distribusi responden berdasarkan umur

\begin{tabular}{ccc}
\hline Kelompok Umur & N & Persen \\
\hline $20-30$ & 8 & 40.0 \\
$31-40$ & 9 & 45.0 \\
$41-50$ & 3 & 15.0 \\
\hline Total & 20 & 100.0 \\
\hline
\end{tabular}

Tabel diatas menunjukkan bahwa responden yang umur 31-40 tahun lebih banyak yaitu berjumlah 9 orang, dengan presentase $45 \%$, dibandingkan dengan kelompok umur 20-30 tahun (40\%) dan 4150 tahun (15\%).

Tabel 2. Distribusi responden berdasarkan lama kerja

\begin{tabular}{ccc}
\hline Lama Kerja & $\mathrm{N}$ & Persen \\
\hline$<6$ tahun & 12 & 85.0 \\
$6-10$ tahun & 6 & 10.0 \\
$>10$ tahun & 2 & 5.0 \\
\hline Total & 20 & 100.0 \\
\hline
\end{tabular}

Tabel dua menunjukkan data berdasarkan lama bekerja sebagai petugas di Bandara, petugas yang termasuk dalam kelompok kurang dari 6 tahun adalah yang paling banyak yaitu sebanyak 12 orang dengan persentase $60 \%$, Dibandingkan kelompok umur 6-10 tahun (30\%) dan lebih dari 10 tahun (10\%). 
Tabel 3. Distribusi responden berdasarkan durasi kerja (jam/hari)

\begin{tabular}{ccc}
\hline Durasi kerja (jam/hari) & $\mathrm{N}$ & Persen \\
\hline$<10$ jam & 8 & 40.0 \\
$\geq 10$ jam & 12 & 60.0 \\
\hline Total & 20 & 100.0 \\
\hline
\end{tabular}

Berdasarkan data hasil penelitian yang telah dilakukan durasi kerja dalam sehari terbanyak adalah para petugas yang memiliki durasi keæja 10 jam yaitu sebanyak 12 dengan presentase 60\% dibandingkan dengan petugas dengan durasi kerja kurang dari 10 jam yaitu 8 orang (40\%).

Tabel 4. Distribusi responden berdasarkan durasi kerja (hari/minggu)

\begin{tabular}{ccc}
\hline $\begin{array}{c}\text { Durasi kerja } \\
\text { (hari/minggu) }\end{array}$ & $\mathrm{N}$ & Persen \\
\hline$\leq 5$ & 16 & 80.0 \\
$>5$ & 4 & 20.0 \\
\hline Total & 20 & 100.0 \\
\hline
\end{tabular}

Berdasarkan data hasil penelitian, durasi kerja data seminggu terbanyak adalah petugas yang memiliki durasi kerja $\leq 5$ hari yaitu 16 orang dengan presentase $80 \%$, dibandingkan petugas yang memiliki durasi kerja lebih dari 5 hari (20\%).

Tabel 5. Distribusi responden berdasarkan tingkat intensitas bising

\begin{tabular}{ccc}
\hline Tingkat bising & N & Persen \\
\hline $75 \mathrm{~dB}$ & 9 & 45.0 \\
$85 \mathrm{~dB}$ & 11 & 55.0 \\
\hline Total & 20 & 100.0 \\
\hline
\end{tabular}

Berdasarkan hasil pengukuran yang telah dilakukan menggunakan alat Sound Level Meter didapatkan hasil tebanyak adalah petugas yang bekerja pada tingkat bising $85 \mathrm{~dB}$ yaitu sebanyak 11 orang dengan presentase $55 \%$ dan 9 orang pada tingkat bising $75 \mathrm{~dB}$ (45\%).
Tabel 6. Distribusi responden berdasarkan ketaatan Alat PelindungTelinga (APT).

\begin{tabular}{ccc}
\hline Pemakaian APT & $\mathrm{N}$ & Persen \\
\hline sering dipakai & 10 & 50.0 \\
jarang dipakai & 10 & 50.0 \\
\hline Total & 20 & 100.0 \\
\hline
\end{tabular}

Berdasarkan data hasil penelitian yang didapatkan petugas yang sering memakai APT berjumlah 10 orang dengan presentase $50 \%$ dan yang jarang memakai APT berjumlah 10 orang (50\%).

Tabel 7. Distribusi responden berdasarkan jenis Alat Pelindung Telinga (APT) yang digunakan

\begin{tabular}{ccc}
\hline Jenis APT & $\mathrm{N}$ & Persen \\
\hline Earmuff & 1 & 5.0 \\
Earplug & 19 & 95.0 \\
\hline Total & 20 & 100.0 \\
\hline
\end{tabular}

Tabel 7. menunjukkan pemakaian alat pelindung telinga jenis earmuff sebanyak 1 orang dengan persentase 5\% dan pemakaian alat pelindung telinga jenis earplug sebanyak 19 orang dengan persentase 95\%.

Tabel 8. Distribusi responden berdasarkan gangguan pendengaran

\begin{tabular}{ccc}
\hline Hasil & $\mathrm{N}$ & Persen \\
\hline Normal & 16 & 80.0 \\
Tuli & 4 & 20.0 \\
\hline Total & 20 & 100.0 \\
\hline
\end{tabular}

Dari hasil penelitian dengan melakukan hasil pemeriksaan fungsi pendengaran menggunakan audiometri terdapat 4 orang (20\%) yang menderita tuli dan 16 orang (80\%) yang normal.

Tabel 9. Distribusi responden berdasarkan derajat ketulian telinga kanan 


\begin{tabular}{ccc}
\hline Hasil & $\mathrm{N}$ & Persen \\
\hline Normal & 16 & 80.0 \\
tuli ringan & 4 & 20.0 \\
\hline Total & 20 & 100.0 \\
\hline
\end{tabular}

Setelah dilakukan pemeriksaan fungsi pendengaran telinga kanan dapat dilihat 4 orang (20\%) mengalami tuli ringan dan 16 orang $(80 \%)$ yang normal.

Tabel 10. Distribusi responden berdasarkan derajat ketulian telinga kiri

\begin{tabular}{ccc}
\hline Hasil & $\mathrm{N}$ & Persen \\
\hline Normal & 16 & 80.0 \\
tuli ringan & 3 & 15.0 \\
tui sedang & 1 & 5.0 \\
\hline Total & 20 & 100.0 \\
\hline
\end{tabular}

Setelah dilakukan pemeriksaan fungsi pendengaran telinga kiri dapat dilihat 3 orang $(15 \%)$ menderita tuli ringan, 1 orang (5\%) menderita tuli sedang dan 16 orang (80\%) yang normal.

Tabel 11. Distribusi responden berdasarkan intensitas bising dan durasi kerja dalam seminggu.

\begin{tabular}{cccc}
\hline $\begin{array}{c}\text { Durasi kerja } \\
\text { jam/minggu }\end{array}$ & \multicolumn{2}{c}{ Intensitas bising } & Total \\
\hline 32 jam & 1 & $85 \mathrm{~dB}$ & \\
40 jam & 1 & 2 & 2 \\
48 jam & 1 & 3 & 4 \\
50 jam & 0 & 1 & 1 \\
55 jam & 0 & 2 & 2 \\
56 jam & 1 & 1 & 2 \\
60 jam & 4 & 1 & 5 \\
84 jam & 1 & 0 & 1 \\
\hline Total & 9 & 11 & 20 \\
\hline
\end{tabular}

Tabel 11 menunjukkan petugas yang bekerja pada intensitas bising $75 \mathrm{~dB}$ dengan durasi kerja terlama yaitu 1 orang (84 jam/minggu), sedangkan petugas pada intensitas $85 \mathrm{~dB}$ dengan durasi kerja terlama yaitu 1 orang (60 jam/minggu).
Berdasarkan analisis bivariat terdapat 2 sel yang memiiki harapan kurang dari 5 dan jumlah sampel yang kurang dari 40 sampel, sehingga tidak memenuhi kriteria untuk dilakukan Uji Chi-Square sehingga dilakukan Uji alternatif lain yaitu Fisher Exact dengan nilai sampel kurang dari 40 dan nilai harapan kurang dari lima. Nilai Uji Fisher Exact didapatkan p $=0.591$ $(\mathrm{p}=<0.05)$.

\section{BAHASAN}

\section{Berdasarkan hasil pemeriksaan pendengaran dengan menggunakan audiometri nada murni didapatkan Pure} Tone Average (PTA) yaitu 4 orang mengalami gangguan pendengaran pada kedua telinganya (20\%), 16 orang normal sedangkan 1 orang walaupun PTA dalam batas normal tetapi telah mengalami penurunan pada frekwensi $4000 \mathrm{~Hz}$ (80\%). Menurut kepustakaan yang didapat mengatakan bahwa stadium dini dari tuli akibat paparan bising ditandai dengan kurva ambang pendengaran yang curam pada frekwensi diantara 3000 dan 6000 HZ, biasanya pertama kali timbul pada nada 4000 Hz. Tingkat ketulian ditentukan dengan menggunakan kriteria ISO (International Standard Organitation) dengan patokan normal yaitu 0-25 dB. ${ }^{7}$

Berdasarkan data yang diperoleh, menunjukkan bahwa petugas terbanyak ada pada kelompok umur 31-40 tahun dengan usia terendah 23 tahun dan tertinggi 49 tahun. Pada tabel 2 dapat dilihat bahwa petugas dengan lama kerja kurang dari 6 tahun lebih banyak yaitu sebanyak 12 orang (60\%) jika dibandingkan dengan petugas dengan lama kerja 6-10 tahun dan diatas 10 tahun. Sedangkan, pada tabel 5 menunjukkan bahwa petugas yang bekerja pada intensitas bising $75 \mathrm{~dB}$ berjumlah 9 
orang, memang lebih sedikit jika dibandingkan dengan petugas yang bekerja pada intensitas $85 \mathrm{~dB}$ yang berjumlah 11 orang. menurut tinjauan pustaka yang didapat menyebutkan bahwa semakin tinggi intensitas kebisingan dan semakin lama waktu pemaparan kebisingan yang dialami oleh para pekerja, semakin berat gangguan pendengaran yang ditimbulkan pada pekerja tersebut. $^{8}$ Kepustakaan lain menyatakan bahwa seseorang yang bekerja di lingkungan bising terutama yang telah bekerja lebih dari lima tahun, kemungkinan besar bisa terkena penyakit tuli syaraf koklea yang tidak dapat disembuhkan. ${ }^{9}$ Hal ini menunjukkan bahwa ada hubungan yang erat antara tingkat intensitas bising dan lamanya bekerja dengan terjadinya gangguan pendengaran. Pada Tabel 11 menunjukkan berdasarkan data hasil penelitian di dapatkan 8 petugas yang bekerja pada intensitas bising $85 \mathrm{~dB}$ yang memiliki jam kerja lebih dari 40 jam dalam seminggu. Ini menunjukkan bahwa 8 orang dari 20 petugas telah melebihi nilai ambang batas kebisingan yang telah di tetapkan oleh Menteri Tenaga Kerja nomor KEP-51/MEN/1999. ${ }^{10}$ Sesuai data yang diperoleh dari kuesioner didapatkan 10 orang yang jarang memakai APT dan 10 orang yang sering memakai APT dan dari 8 orang petugas yang telah melebihi NAB didapatkan 5 orang yang jarang memakai APT dan 3 orang yang sering memakai APT.

Ketulian akibat bising adalah akibat pemaparan pemaparan yang berulang selama suatu jangka waktu yang panjang. Ketulian yang diakibatkan oleh bising memberikan gambaran kerusakan telinga dalam yang sangat bervariasi dari kerusakan ringan pada sel rambut sampai kerusakan total organ corti. Proses pasti kejadian tersebut belum diketahui secara lengkap, tetapi agaknya stimulasi berlebihan oleh bising dalam jangka waktu lama mengakibatkan perubahan metabolik dan vaskuler yang pada akhirnya menyebabkan perubahan degeneratif pada bentuk sel. ${ }^{7}$

Penelitian sebelumnya yang pernah dilakukan antara lain, pada petugas ground handling di bandara Ngurah Rai Bali. Penelitian dilakukan pada 44 orang petugas, yakni 6 orang pekerja administrasi dan 38 pekerja divisi teknik. Kedua tempat ini mempunyai tingkat intensitas bising yang berbeda yaitu administrasi 46,9-52 dB dan divisi teknik 88,3-90,9 dari penelitian ini didapatkan hasil pekerja yang mengalami gangguan pendengaran adalah pekerja administrasi tuli 1 orang (16,7\%), 5 orang normal (83.3\%) dan divisi teknik tuli 23 orang (60,5\%), 15 orang normal (39.5\%). ${ }^{11}$

Berdasarkan penelitian sebelumnya diatas dapat ditarik kesimpulan bahwa petugas yang bekerja pada intensitas bising yang tinggi lebih beresiko mengalami gangguan pendengaran dibandingkan dengan petugas yang bekerja pada tingkat intesitas bising yang rendah.

Berdasarkan pembahasan diatas maka didapatkan hasil uji fisher exact $\mathrm{p}=0.591$. Hal ini sesuai dengan tinjauan pustaka yang menyebutkan bahwa banyak hal yang mempermudah seseorang menjadi tuli akibat terpapar bising antara lain intensitas bising yang lebih tinggi, frekwensi tinggi, lebih lama terpapar bising, kepekaan individu dan faktor lain yang dapat menimbulkan ketulian. ${ }^{12}$ Berdasarkan teori tersebut berarti intensitas bising bukanlah satu-satunya faktor yang menyebabkan ketulian. Sehingga tidak heran pada hasil analisis bivariat menggunakan uji fisher exact mendapatkan hasil yang tidak signifikan oleh karena petugas yang bekerja pada intensitas yang melebihi NAB pendengaran yang telah ditetapkan lebih sedikit jika dibandingkan dengan petugas yang bekerja pada intesitas bising yang telah sesuai 
dengan NAB yang di tetapkan, selain itu faktor-faktor seperti lama bekerja, lama pemaparan bising, penggunaan Alat Pelindung Telinga (APT) juga sangat berpengaruh terhadap terjadinya gangguan pendengaran pada petugas. Hal ini sesuai dengan kepustakaan yang menyatakan bahwa APT jenis ear muff dapat mengurangi kebisingan 25-40 dB dan APT jenis ear plug dapat mengurangi kebisingan $8-30 \mathrm{~dB} .{ }^{14}$

\section{SIMPULAN DAN SARAN}

\begin{abstract}
Berdasarkan hasil pemeriksaan pendengaran menggunakan audiometri didapatkan 4 orang petugas menderita tuli dan 16 orang petugas normal. Dari hasil analisis bivariat data yang diperoleh melalui uji fisher exact menunjukkan nilai $\mathrm{p}=0.591$ $(\mathrm{p}=<0.05)$ yang berarti data tidak signifikan. Ini memberi bukti bahwa tidak terdapat hubungan antara kebisingan dan fungsi pendengaran pada petugas PT. Gapura Angkasa di Bandara Sam Ratulangi Manado. Sehingga dapat dikatakan bahwa tingkat intensitas bising di Bandara Sam Ratulangi tidak berpengaruh terhadap terjadinya gangguan pendengaran pada pekerja.

Perlu ditingkatkan lagi kesadaran petugas bandara terhadap penggunaan Alat Pelindung Telinga (APT) sebagai alat yang dapat mengurangi tingkat paparan bising dalam mencegah terjadinya gangguan pendengaran akibat bising.
\end{abstract}

\section{DAFTAR PUSTAKA}

1. Kementerian lingkungan hidup. 2013. Pengkajian Kebisingan lingkungan. http://www.menlh.go.id/pengkajian- kebisingan-pemukiman/. Diakses pada tanggal 23 September 2013

2. Soetjipto, D,. 2007. Noise Induced Hearing Loss / NIHL. http://ketulian.com/v1/web/index.ph p?to=article\&id=15. Diakses pada tanggal 23 September 2013

3. Ali I. Mengatasi Gangguan pada Telinga dengan Tanaman Obat. Jakarta : Agromedia Pustaka, 2006; p. 1-14.

4. Kawatu P.A.T. Buku Ajar Kesehatan Keselamatan Kerja. Manado : FKM, 2012; p. 34-43.

5. Gabriel. J.F. Fisika Kedokteran. Jakarta : ECG, 1996; p.82-95.

6. Munilson. J, Jacky, Edward.Y , Hafiz. A. 2012. Gangguan Pendengaran Akibat Bising: Tinjauan Beberapa Kasus. http://repository.unand.ac.id/id/eprint /17671. Diakses pada tanggal 23 September 2013.

7. Ballenger JJ. Penyakit Telinga Hidung Tenggorok Kepala dan Leher. Jakarta : Binarupa Aksara; 1997. h. 305-331.

8. Rambe A.Y.M. 2003. Gangguan pendengaran akibat bising. http://library.usu.ac.id/download/fk/t ht-andrina1.pdf. Diakses pada tanggal 23 september 2013.

9. Rusiyati, Nurjazuli, Suhartono. Hubungan Paparan Kebisingan Dengan Gangguan Pendengaran Pada Pekerja Industri Kerajinan Pandai Besi Di Desa Hadipolo Kecamatan Jekulo Kabupaten Kudus. Jurnal. Vol.11, No.2. Kudus; Universitas Diponegoro. 2012.

10. Keputusan Menteri Tenaga Kerja., 1999. Nomor: KEP-51/MEN/1999. Tentang. Nilai Ambang Batas Faktor Fisika di Tempat Kerja. http://pusatk3.com/kepmenaker-no- 
kep-51men1999-2/. Diakses pada tanggal 23 September 2013

11. Yadnya IW, Putra NA, Aryanta IWR. Tingkat Kebisingan dan Tajam Dengar Petugas Ground Handling di Bandara Ngurah Rai Bali. Jurnal. Vol. 4, No. 2. Bali; Universitas Udayana. 2012

12. Kusmindari CD. Pengaruh Intensitas Kebisingan pada Proses Sugu dan Proses Ampelas Terhadap Pendengaran Tenaga Kerja di Bengkel Kayu X. http://blog.binadarma.ac.id/desi/wpcontent/uploads/2011/03/04-desiintensitas-bunyi-edit-desi.pdf.

diakses pada tanggal 14 januari 2014

13. Buchari. 2007. Kebisingan Industri dan Hearing Conservation Program. http://library.usu.ac.id/download/ft/0 7002749.pdf. diakses pada tanggal 23 september 2013 